Bangladesh J. Bot. 48(2): 253-263, 2019 (June)

\title{
GENETIC VARIABILITY, EVALUATION AND CHARACTERIZATION OF SUNFLOWER (HELIANTHUS ANNUUS L.) GERMPLASM
}

\author{
Vivek K Singh, RK Sheoran ${ }^{*}$, Subhash Chander ${ }^{1}$ and Bunty Sharma ${ }^{2}$ \\ Department of Genetics and Plant Breeding, CCS Haryana Agricultural University, \\ Hisar, 215004, India
}

Keywords: Characterization, Evaluation, Genetic variability, Sunflower

\begin{abstract}
Fifty accessions of sunflower germplasm were characterized and evaluated for seed yield and its components traits to study the variability present among different germplasm lines. Significant amount of genetic variability was observed for all the characters under study. Seed yield and hull content were identified for highest genotypic (27.08 and $20.14 \%$, respectively) and phenotypic coefficients of variation (27.89 and $20.64 \%$, respectively) and also for high heritability (97.46 and $97.28 \%$, respectively) coupled with high genetic advance (52.19 and $40.49 \%$, respectively) over mean followed by duration of reproductive phase, oil content, 100-seed weight and plant height. Qualitative traits also showed wide variation among the accessions. Majority of the accessions were early in flowering, medium in maturity and medium in head diameter. Among all the accessions, ten lines were observed with short height and ten lines showed high oil content (> 40\%). Maximum genetic distance was observed between the accessions EC-601800 and EC512687 and utilization of these accessions has been advocated in breeding programme. The results of the present study can be useful for the formation of data base and reference lines, genotype identification and will also be helpful in amplification of future sunflower improvement programme.
\end{abstract}

\section{Introduction}

Sunflower (Helianthus annuus L.) is an important oilseed crop, which belongs to the genus 'Helianthus' of the family Asteraceae. It is widely adopted and accepted for its high quality and nutritional edible oil. Due to its high economic importance, the developments of effective hybrids are required with superior yield and quality traits. Presence/existence of ample amount of genetic variability is prerequisite before embarking any breeding programme. Information of variability and heritability is useful to formulate selection criteria for improvement of seed yield and its component traits. Heritability estimates along with genetic advance is a more reliable measure in predicting the expected performance/progress to be achieved during selection. Hence, variability present in a gene pool of a crop species is important to plant breeder for breeding programme. The coefficients of variation expressed at phenotypic and genotypic levels are used to compare the variability among different characters for identifying the character association and selection of the superior genotype. A wide range of variation has been reported for seed yield and seed number (Velkov 1980) and other important yield attributing components (Virupakshappa and Sindagi 1988) in sunflower. The heritability estimates aid in determining the relative amount of heritable portion in variation and thus help plant breeder in selecting the elite lines from a diverse population. However, the heritability estimates along with genetic advance are more helpful in predicting the gain under selection than heritability estimates alone. Classification of germplasm based on agronomic characters plays an important role in plant breeding to select valuable genetic resources to be utilized later in different breeding programmes. Further, characterization could be utilized for varietal identification in seed production programmes, maintaining the genetic purity of a genotype, and also DUS testing becomes easy in a well characterized genotype. Germplasm

*Authors for correspondence: <sheoranrk@yahoo.com>. ${ }^{1}$ International Institute of Tropical Agriculture, Ibadan, Nigeria; ${ }^{2}$ Chitkara University, Punjab, India. 
of a specific crop collected from the diverse sources offers greater genetic diversity and may further useful to widen the genetic base of crop species. Hence, the present study was conducted to evaluate the extent of genetic variability, heritability and genetic advance over mean for seed yield and its components traits in sunflower. Moreover, the present material was also characterized based on quantitative (8) and qualitative (26) traits by giving scores in accordance with the standard DUS guideline on sunflower.

\section{Materials and Methods}

The present study was conducted in the research farm of the Oilseeds Section, Department of Genetics and Plant Breeding, CCS Haryana Agricultural University, Hisar, Haryana, India. Monthly average temperature (maximum and minimum) and rainfall during the research period are presented in Fig. 1.

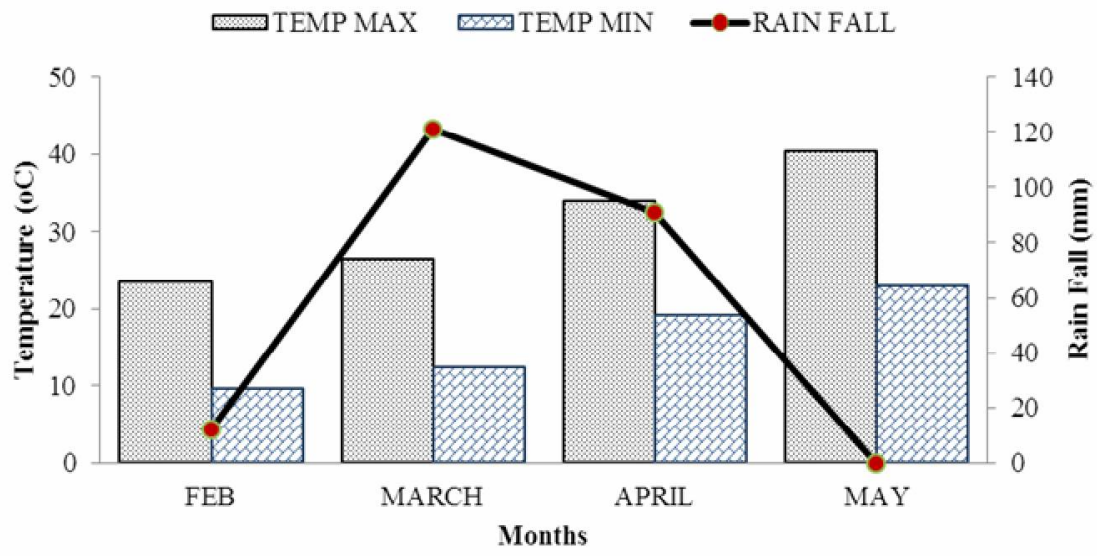

Fig.1. Monthly, average temperature $\left({ }^{\circ} \mathrm{C}\right)$ and rainfall $(\mathrm{mm})$ during crop season 2015.

The present study comprised 50 germplasm of sunflower lines, maintained by the Oilseeds Section, Department of Genetics and Plant Breeding, CCS Haryana Agricultural University, Hisar.

The experiment was laid out in a randomized complete block design (RCBD) with three replications, in spring season, 2015 having double row plot of $3.5 \mathrm{~m}$ length of each accession per replication maintaining row to row and plant to plant distance of 60 and $30 \mathrm{~cm}$, respectively. Standard agronomic practices were performed uniformly for all the experimental units.

At maturity five plants from each accession were selected randomly for recording of data on yield and its related characters viz. days to 50\% flowering, duration of reproductive phase (days), days to maturity, plant height $(\mathrm{cm})$, stem girth $(\mathrm{cm})$, head diameter $(\mathrm{cm})$, seed yield $(\mathrm{g}), 100$-seed weight $(\mathrm{g})$, seed volume weight $(\mathrm{g} / 100 \mathrm{ml})$, hull content $(\%)$ and oil content $(\%)$. The accessions were characterized on the basis of recommended qualitative characters as per DUS guidelines (Dhillon et al. 2010).

The genotypic coefficients of variation (GCV) and phenotypic coefficients of variation (PCV) were computed according to the methods suggested by Burton and Devane (1953), heritability $\left(\mathrm{h}^{2}\right)$ by Hanson et al. (1956) and expected genetic advance over mean (GAM) as suggested by Johnson et al. (1955). Dendrogram was prepared to form different clusters of accessions and to estimate genetic similarities among these by using the software XLSTAT. 


\section{Results and Discussion}

The analysis of variance revealed highly significant differences for all characters (Table 1). Mean, range, genotypic and phenotypic coefficients of variation, heritability and genetic advance in per cent of mean for the respective characters were estimated (Table 2). The range of variation was maximum for plant height $(102.00-169.07 \mathrm{~cm})$ followed by seed yield $(13.83-50.93 \mathrm{~g})$ and hull content $(31.13-65.70 \%)$, while it was lowest in the case of 100 -seed weight $(3.46-6.47 \mathrm{~g}$ ) and stems girth $(5.67-8.73 \mathrm{~cm})$. The values of PCV were marginally higher than GCV. This indicates that the large amount of variation was contributed by genetic component and least by environment. Duration of reproductive phase and stem girth was most affected by environment as compared with the other characters. Very high values of PCV and GCV were obtained for seed yield (27.08 and $27.89 \%)$, hull content (20.14 and 20.64\%), duration of reproductive phase (17.95 and $19.55 \%)$ and oil content (15.16\% and $15.28 \%)$, which indicates significant role of these characters in the improvement of breeding programmes. These results are similar with those of Virupakshppa and Sindagi (1988), Gangappa (1991), Suma and Virupakshappa (1994), Patil et al. (1996), Reddy and Reddy (2006), Kalukhe et al. (2010). Moderate levels of PCV and GCV were obtained for the 100-seed weight, plant height, head diameter, seed volume weight and stem girth in the decreasing order of magnitude. These results are in agreement with the results obtained by Patil et al. (1996). However, low values were obtained for days to maturity (3.70 and 3.83\%) (Satisha 1995). Seed yield per plant was identified for having high heritability $(97.46 \%)$ while lowest for stem girth $(57.50 \%)$.

Table 1. Analysis of variance for seed yield and yield component in sunflower.

\begin{tabular}{|c|c|c|c|c|c|}
\hline \multirow{3}{*}{ Source of variation } & \multicolumn{4}{|c|}{ Mean sum of square } & \multirow{3}{*}{$\mathrm{CV}(\%)$} \\
\hline & & Replication & Genotype & Error & \\
\hline & $\mathrm{df}$ & 2 & 49 & 149 & \\
\hline Seed yield per plant $(\mathrm{g})$ & & 15.802 & $284.142^{* *}$ & 16.100 & 11.495 \\
\hline Days to $50 \%$ flowering (days) & & 4.740 & $46.324 * *$ & 16.951 & 6.573 \\
\hline Duration of reproductive phase (days) & & 4.037 & $16.529 * *$ & 3.250 & 11.734 \\
\hline Days to maturity (days) & & 3.927 & $46.357 * *$ & 17.403 & 4.513 \\
\hline Plant height $(\mathrm{cm})$ & & 13.716 & $1003.689 * *$ & 15.507 & 3.080 \\
\hline Stem girth $(\mathrm{cm})$ & & 2.116 & $1.271 * *$ & 0.251 & 6.758 \\
\hline Head diameter $(\mathrm{cm})$ & & 0.787 & $4.344 * *$ & 1.091 & 8.332 \\
\hline 100-seed weight (g) & & 0.062 & $1.852^{* *}$ & 0.196 & 8.983 \\
\hline Seed volume weight $(\mathrm{g} / 100 \mathrm{ml})$ & & 2.796 & $27.326^{* *}$ & 2.228 & 4.178 \\
\hline Hull content $(\%)$ & & 17.387 & $311.118^{* *}$ & 14.827 & 7.804 \\
\hline Oil content (\%) & & 1.194 & $86.412 * *$ & 1.331 & 3.284 \\
\hline
\end{tabular}

Estimates of high heritability obtained by these characters were governed by additive gene effects (Panse 1957) and these characters are amendable for improvement by selection, particularly through mass selection (Krishnawat and Sharma 1988, Ashok et al. 2000). The high heritability magnitude indicates the reliability, which represent the high chance of the genotype to be recognized by its phenotypic expression. This result is in accordance with the previous results (Mogali 1993, Satisha 1995, Manjula 1997). Moderate heritability of oil content was reported by Fick 1974, Gangappa 1991, Makane et al. 2011). 
The genetic advance in per cent of mean varied from 7.37 to 54.19 for days to maturity and seed yield per plant, respectively. High heritability values coupled with high genetic advance in per cent of mean was recorded for seed yield per plant, hull content and duration of reproductive phase. This indicates generous scope for improving these characters through simple selection. Similar results were also reported by Srivastava and Mishra (1976) and Singh et al. (1977). High heritability coupled with moderate genetic advance was observed for plant height, 100-seed weight and head diameter. Similar results were reported earlier by Manjula (1997) and Lakshmanaiah (1980). High heritability along with low genetic advance was noticed for the days to maturity, stem girth and days to $50 \%$ flowering and these results were in conformity with those of Kshirsagar et al. (1995) and Satisha (1995).

Table 2. Range, mean, coefficients of variation, heritability and genetic advance for 11 quantitative traits in sunflower.

\begin{tabular}{|c|c|c|c|c|c|c|c|c|}
\hline \multirow[t]{2}{*}{ Characters } & \multirow[t]{2}{*}{ Mean \pm SE } & \multicolumn{2}{|l|}{ Range } & \multicolumn{2}{|c|}{ Coefficient of variation } & \multirow{2}{*}{$\begin{array}{l}\text { Heritability } \\
\text { (b.s.) }\end{array}$} & \multirow{2}{*}{$\begin{array}{l}\text { Genetic } \\
\text { advance }\end{array}$} & \multirow[t]{2}{*}{ GAM } \\
\hline & & Min. & Max. & Genotypic & Phenotypic & & & \\
\hline SY & $34.90 \pm 2.32$ & 13.83 & 50.93 & 27.08 & 27.89 & 97.46 & 18.91 & 54.19 \\
\hline DF & $62.64 \pm 2.38$ & 56.33 & 71.33 & 6.20 & 6.27 & 93.06 & 7.90 & 12.61 \\
\hline $\mathrm{RP}$ & $15.36 \pm 1.04$ & 10.97 & 19.67 & 17.95 & 19.55 & 90.34 & 5.44 & 33.95 \\
\hline DM & $92.43 \pm 2.41$ & 86.33 & 101.00 & 3.70 & 3.83 & 82.63 & 6.46 & 7.37 \\
\hline $\mathrm{PH}$ & $127.85 \pm 2.27$ & 102.00 & 169.07 & 14.20 & 14.31 & 95.50 & 37.10 & 29.02 \\
\hline SG & $7.42 \pm 0.29$ & 5.67 & 8.73 & 7.86 & 8.78 & 57.50 & 1.08 & 14.50 \\
\hline HD & $12.54 \pm 0.60$ & 9.83 & 15.07 & 11.26 & 11.73 & 79.73 & 2.80 & 22.27 \\
\hline SW & $4.93 \pm 0.26$ & 3.46 & 6.47 & 15.06 & 15.93 & 73.76 & 1.45 & 29.33 \\
\hline SVW & $35.73 \pm 0.86$ & 30.52 & 45.52 & 8.10 & 8.45 & 78.97 & 5.71 & 15.98 \\
\hline $\mathrm{HC}$ & $49.34 \pm 2.22$ & 31.13 & 65.70 & 20.14 & 20.64 & 97.28 & 19.98 & 40.49 \\
\hline OC & $35.13 \pm 0.67$ & 27.35 & 45.81 & 15.16 & 15.28 & 95.52 & 10.89 & 30.99 \\
\hline
\end{tabular}

$\mathrm{GAM}=$ Genetic advance as \% of mean, $\mathrm{SY}=$ Seed yield per plant $(\mathrm{g}), \mathrm{DF}=$ Days to $50 \%$ flowering (days), $\mathrm{RP}=$ Duration of reproductive phase (days), $\mathrm{DM}=$ Days to maturity (days), $\mathrm{PH}=$ Plant height $(\mathrm{cm}), \mathrm{SG}=$ Stem girth $(\mathrm{cm}), \mathrm{HD}=$ Head diameter $(\mathrm{cm}), \mathrm{SW}=100$-seed weight $(\mathrm{g}), \mathrm{SVW}=$ Seed volume weight $(\mathrm{g} / 100$ $\mathrm{ml}), \mathrm{HC}=$ Hull content $(\%)$ and $\mathrm{OC}=$ Oil content $(\%)$.

Classification and characterization of all 50 sunflower accessions into different categories of quantitative traits was done (Table 3). The accession MR-6 showed the highest stem girth $(8.7 \mathrm{~cm})$ and seed volume weight (45.5g) and EC-512687 exhibited late maturity (97 days); highest plant height $(169 \mathrm{~cm})$. Encheva et al. (2008) and Onemli and Gucer (2010) reported significant differences in plant height, head diameter, and period of flowering of sunflower wild genotypes. The accessions RHA-265, HRHA-271-P3, RHA-297-P2, IB-43, ACC-350-2, MSF-1-7, AH-14, IHT-201, IHT-298, NDR-2 and GPB-07 showed early flowering ( $<60$ days) but considering maturity ACC-350-2 (86 days) was the earliest; but accessions EC-601746, EC-512687 and EC601800 (71 days) were late in flowering but EC-512687, EC-152681and EC-601746 ( $\geq 100$ days) took highest number of days to mature which exhibited direct relation between earliness or lateness in flowering and maturity. Considering plant height EC-512687 was the tallest $(169 \mathrm{~cm})$ and MSF-2-16 $(102 \mathrm{~cm})$ was dwarf. Head diameter was largest in EC-152673 $(15.1 \mathrm{~cm})$; EC152686 and EC-152687 $(14.7 \mathrm{~cm})$ but smallest in ACC-350-2 $(9.8 \mathrm{~cm})$. Considering oil per cent, the genotype MSF-1-4 (45.8\%) produced the highest mean along with duration of reproductive 
period (21) and EC-152686 (27.3\%) produced the lowest mean oil content. Considering 100-seed weight, the genotype RHA-265 $\mathrm{P}_{3}$ had the highest mean of $6.5 \mathrm{~g}$ and revealed to be a promising accession for confectionary purpose. Accessions which have high seed weight and oil content are categorized as potential accessions because seed weight is one of important considerable yield components (Dehkhoda et al. 2013, Rafiei et al. 2013, Ion et al. 2015). The lowest hull content (31\%) was recorded from MR-6 and highest in HB-15 (65\%). Maximum seed yield per plant was observed in accession EC-601755 (50.9g) followed by 1-OH-07-41 and GPB-6, which can be used for breeding for high yielding lines.

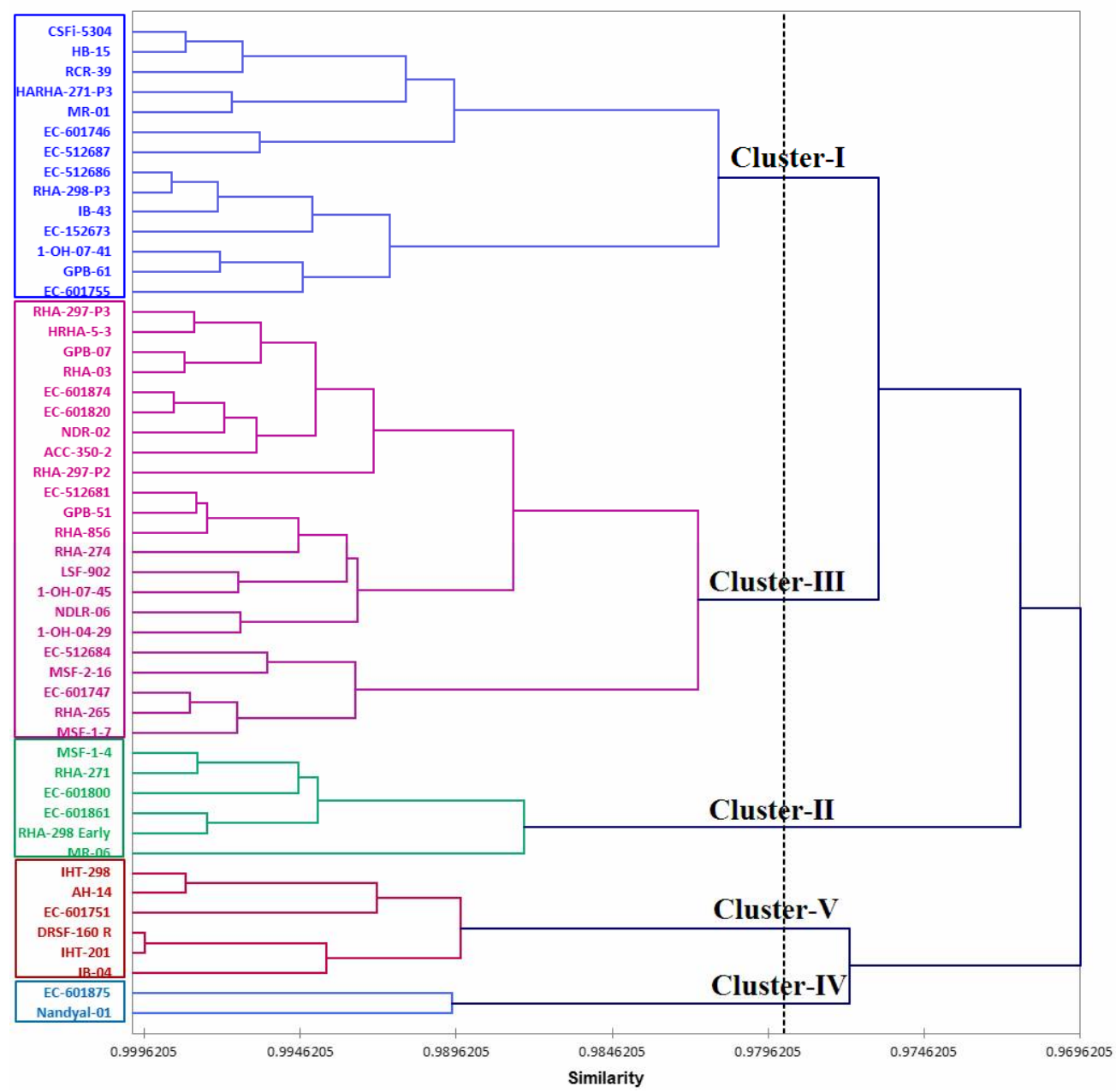

Fig. 2. Dendrogram showing the genetic distances amongst different sunflower accessions.

Qualitative traits such as leaf blistering, leaf colour, leaf serration, stem pigmentation and ray floret: shape, colour etc. were examined after 60 days after sowing. Classification and characterization of all the sunflower accessions on the basis of qualitative traits are presented in Table 4, which indicate wide variation for all the qualitative characters (except pollen colour) which is in conformity with the results reported by Makane et al. (2011). Tan and Tan (2011) also reported that the morphological variation on the characters was high. Out of 50 accessions, most 
of accessions were absent for hypocotyl anthocyanine pigmentation, medium leaf size, cordate leaf shape, green leaf colour, medium leaf bristers, acute angle, erect leaf orientation of blade, elongate and yellow ray floret, convex head shape and black base colour of seed coat with grey strip. Sixty per cent of accessions were medium and $38 \%$ were coarse for leaf serration. This character could be used to distinguish extreme genotypes (Diederichsen 2010). About 50\% and 99\% accessions were absent on leaf petiole and bract anthocyanine pigmentation, respectively.

Table 3. Grouping of germplasm on the basis of quantitative characters.

\begin{tabular}{|c|c|c|c|c|}
\hline Sl. No. & Characteristics & Expression & No. of accessions & Percentage \\
\hline \multirow[t]{3}{*}{1} & Days to $50 \%$ flowering (days) & Early $(>60)$ & 11 & 22 \\
\hline & & Medium (60-75) & 39 & 78 \\
\hline & & Late $(>75)$ & 0 & 0 \\
\hline \multirow[t]{5}{*}{2} & Plant height $(\mathrm{cm})$ & Very short $(<80)$ & 0 & 0 \\
\hline & & Short (80-110) & 10 & 20 \\
\hline & & Medium (111-140) & 23 & 46 \\
\hline & & Tall (141-170) & 14 & 28 \\
\hline & & Very tall $(>170)$ & 3 & 6 \\
\hline \multirow[t]{3}{*}{3} & Head diameter $(\mathrm{cm})$ & Small $(<15)$ & 35 & 70 \\
\hline & & Medium (15-20) & 15 & 30 \\
\hline & & Large $(>20)$ & 0 & 0 \\
\hline \multirow[t]{3}{*}{4} & Ray floret (number) & Few $(<30)$ & 1 & 2 \\
\hline & & Medium (30-40) & 27 & 54 \\
\hline & & Many $(>40)$ & 22 & 44 \\
\hline \multirow[t]{3}{*}{5} & 100 seed weight & Low $(<4)$ & 12 & 24 \\
\hline & & Medium (4-6) & 32 & 64 \\
\hline & & $\operatorname{High}(>6)$ & 6 & 12 \\
\hline \multirow[t]{3}{*}{6} & Seed length $(\mathrm{cm})$ & Short $(<1)$ & 28 & 56 \\
\hline & & Medium (1-1.5) & 22 & 44 \\
\hline & & High $(>1.5)$ & 0 & 0 \\
\hline \multirow[t]{3}{*}{7} & Hull content (\%) & Low $(<25)$ & 0 & 0 \\
\hline & & Medium (25-30) & 0 & 0 \\
\hline & & High $(>30)$ & 50 & 100 \\
\hline \multirow[t]{4}{*}{8} & Oil content (\%) & Low $(<35)$ & 23 & 46 \\
\hline & & Medium $(35-40)$ & 19 & 38 \\
\hline & & High (40-43) & 2 & 4 \\
\hline & & Very high $(>43)$ & 6 & 12 \\
\hline
\end{tabular}


Table 4. Grouping of germplasm on the basis of qualitative characters.

\begin{tabular}{|c|c|c|c|c|}
\hline $\begin{array}{l}\text { Sl. } \\
\text { No. }\end{array}$ & Characteristics & Expression & No. of accessions & Percentage \\
\hline \multirow[t]{3}{*}{1} & \multirow[t]{3}{*}{ Anthocyanin pigmentation } & Absent & 41 & 82 \\
\hline & & Medium & 6 & 12 \\
\hline & & Strong & 3 & 6 \\
\hline \multirow[t]{3}{*}{2} & \multirow[t]{3}{*}{ Leaf size $(\mathrm{cm})$} & Small $(<15)$ & 5 & 10 \\
\hline & & Medium (15-25) & 37 & 74 \\
\hline & & Large $(>25)$ & 8 & 16 \\
\hline \multirow[t]{4}{*}{3} & \multirow[t]{4}{*}{ Leaf shape } & Lanceolate & 0 & 0 \\
\hline & & Triangular & 5 & 10 \\
\hline & & Cordate & 42 & 84 \\
\hline & & Rounded & 3 & 6 \\
\hline \multirow[t]{3}{*}{4} & \multirow[t]{3}{*}{ Leaf colour } & Light Green & 9 & 18 \\
\hline & & Green & 33 & 66 \\
\hline & & Dark Green & 8 & 16 \\
\hline \multirow[t]{3}{*}{5} & \multirow[t]{3}{*}{ Leaf blistering } & Absent & 3 & 6 \\
\hline & & Medium & 31 & 62 \\
\hline & & Strong & 16 & 32 \\
\hline \multirow[t]{3}{*}{6} & \multirow[t]{3}{*}{ Leaf serration } & Fine & 1 & 2 \\
\hline & & Medium & 30 & 60 \\
\hline & & Coarse & 19 & 38 \\
\hline \multirow[t]{2}{*}{7} & \multirow[t]{2}{*}{ Leaf angle of lateral veins } & Acute $\left(<90^{\circ}\right)$ & 43 & 86 \\
\hline & & Obtuse $\left(>90^{\circ}\right)$ & 7 & 14 \\
\hline \multirow[t]{2}{*}{8} & \multirow[t]{2}{*}{ Leaf orientation of blade } & Erect & 31 & 62 \\
\hline & & Drooping & 19 & 38 \\
\hline \multirow[t]{2}{*}{9} & \multirow{2}{*}{$\begin{array}{l}\text { Leaf petiole anthocyanin } \\
\text { pigmentation }\end{array}$} & Absent & 25 & 50 \\
\hline & & Present & 25 & 50 \\
\hline \multirow[t]{2}{*}{10} & \multirow[t]{2}{*}{ Stem pigmentation } & Absent & 49 & 98 \\
\hline & & Present & 1 & 2 \\
\hline \multirow[t]{3}{*}{11} & \multirow[t]{3}{*}{ Ray floret: Shape } & Elongated & 42 & 84 \\
\hline & & Ovate & 8 & 16 \\
\hline & & Rounded & 0 & 0 \\
\hline \multirow[t]{4}{*}{12} & \multirow[t]{4}{*}{ Ray floret: Colour } & Light yellow & 8 & 16 \\
\hline & & Yellow & 34 & 68 \\
\hline & & Orange & 6 & 12 \\
\hline & & Purple & 2 & 4 \\
\hline \multirow[t]{3}{*}{13} & \multirow[t]{3}{*}{ Disk floret: Colour } & Yellow & 13 & 26 \\
\hline & & Orange & 17 & 34 \\
\hline & & Purple & 20 & 40 \\
\hline 14 & Disk floret: Anthocyanin & Absent & 19 & 38 \\
\hline & pig. of stigma & Medium & 19 & 38 \\
\hline & & Strong & 12 & 24 \\
\hline
\end{tabular}




\begin{tabular}{|c|c|c|c|c|}
\hline $\begin{array}{l}\text { Sl. } \\
\text { No. }\end{array}$ & Characteristics & Expression & No. of accessions & Percentage \\
\hline \multirow[t]{2}{*}{15} & \multirow[t]{2}{*}{ Disk floret: Pollen colour } & White & 0 & 0 \\
\hline & & Yellow & 50 & 100 \\
\hline \multirow[t]{2}{*}{16} & \multirow[t]{2}{*}{ Bract: Shape } & Elongated & 26 & 52 \\
\hline & & Rounded & 24 & 48 \\
\hline \multirow[t]{2}{*}{17} & \multirow[t]{2}{*}{ Bract: Anth. pign. } & Absent & 49 & 98 \\
\hline & & Present & 1 & 2 \\
\hline \multirow[t]{2}{*}{18} & \multirow{2}{*}{$\begin{array}{l}\text { Plant: Natural position of } \\
\text { closest lateral head to } \\
\text { central head }\end{array}$} & Above & 5 & 29.41 \\
\hline & & Below & 12 & 70.59 \\
\hline \multirow[t]{4}{*}{19} & \multirow[t]{4}{*}{ Head: Attitude } & Inclined & 9 & 18 \\
\hline & & Vertical & 21 & 42 \\
\hline & & Half turned down & 15 & 30 \\
\hline & & Turned down & 5 & 10 \\
\hline \multirow[t]{4}{*}{20} & \multirow[t]{4}{*}{ Head: Shape of grain side } & Concave & 3 & 6 \\
\hline & & Flat & 11 & 22 \\
\hline & & Convex & 29 & 58 \\
\hline & & Irregular & 7 & 14 \\
\hline \multirow[t]{2}{*}{21} & \multirow[t]{2}{*}{ Plant: Branching } & Absent & 33 & 66 \\
\hline & & Present & 17 & 34 \\
\hline \multirow[t]{3}{*}{22} & \multirow[t]{3}{*}{ Plant: Type of branching } & Basal & 0 & 0 \\
\hline & & Overall & 7 & 14 \\
\hline & & Apical & 10 & 20 \\
\hline \multirow[t]{3}{*}{23} & \multirow[t]{3}{*}{ Seed : Shape } & Elongated & 9 & 18 \\
\hline & & Ovoid elongated & 22 & 22 \\
\hline & & Ovoid wide & 19 & 38 \\
\hline \multirow[t]{4}{*}{24} & \multirow[t]{4}{*}{ Seed coat: Base colour } & White & 0 & 0 \\
\hline & & Grey & 2 & 4 \\
\hline & & Brown & 11 & 22 \\
\hline & & Black & 37 & 74 \\
\hline \multirow[t]{2}{*}{25} & \multirow[t]{2}{*}{ Seed coat: Stripe } & Absent & 30 & 60 \\
\hline & & Present & 20 & 40 \\
\hline \multirow[t]{4}{*}{26} & \multirow[t]{4}{*}{ Seed coat: Colour of stripe } & White & 1 & 5 \\
\hline & & Grey & 17 & 85 \\
\hline & & Brown & 2 & 10 \\
\hline & & Black & 0 & 0 \\
\hline
\end{tabular}

Cluster analysis indicates the extent of genetic diversity in the material that could be used as parental lines in future breeding programmes (Sultana and Ghafoor 2008). The association among different accessions is presented in the form of dendrogram (Fig. 2) prepared using agglomerative hierarchical clustering methods (XLSTAT). Based on quantitative traits, all sunflower accessions by cluster analysis were divided into 5 groups. From the Fig. 2, most of the accessions were included in cluster III and I ( 22 and 14 accessions) followed by cluster II, cluster V (6 accessions) and cluster IV contains only two accessions. The accessions, which are lying nearer to each other in the dendrogram are more similar to one another than those lying away from each other. The 
present dendrogram shows the relatively high magnitude of resemblance among the sunflower accessions in different clusters. Interestingly, the accession CSFI-5304 showed the extreme place from Nandyal-01 meaning thereby that they had maximum genetic distance between them. Likewise the positional distances between all the accessions on $\mathrm{X}$-axis represent the genetic distances between these accessions and use of the accessions with maximum genetic distance is promoted in crossing programmes to develop sunflower hybrids with desirable combination of traits in them.

Table 5. Promising accessions of sunflower for different characters.

\begin{tabular}{|c|c|}
\hline Characters & Accessions \\
\hline $\begin{array}{l}\text { Days to } 50 \% \text { flowering } \\
\text { (<60 days) }\end{array}$ & $\begin{array}{l}\text { RHA-265, MSF-1-7, HRHA-271-P }{ }_{3} \text {, RHA-297-P }, \text { ACC-350-2, IHT-201, } \\
\text { GPB-07, IB-43, MSF-2-16, DRSF-160 R, MSF-1-4, AH-14, IHT-298 and } \\
\text { 1-OH-07-45. }\end{array}$ \\
\hline $\begin{array}{l}\text { Days to maturity } \\
\text { ( }<90 \text { days })\end{array}$ & $\begin{array}{l}\text { ACC-350-2, RHA-271, RHA-265, MSF-1-7, HRHA-271-P }, \text { IB-4, EC- } \\
601875, \text { MR-1, MSF-2-16, CSFI-5304, MSF-1-4, DRSF-160 R, GPB-61 } \\
\text { and EC-601751. }\end{array}$ \\
\hline $\begin{array}{l}\text { Head diameter } \\
(>15 \mathrm{~cm})\end{array}$ & $\begin{array}{l}\text { RHA-297-P }, \text { RHA-298-P }, \text { MSF-1-7, IHT-201, 1-OH-07-41, 1-OH-07-45, } \\
\text { CSFI-5304, LSF-902, NDLR-06, EC-152673, EC-512684, EC-512686, } \\
\text { EC-601751, EC-601755 and EC-601874. }\end{array}$ \\
\hline $\begin{array}{l}\text { Plant height } \\
(<110 \mathrm{~cm})\end{array}$ & $\begin{array}{l}\text { RHA-265, RHA-297-P } 2 \text {, Nandyal-1, IB-4, ACC-350-2, MSF-2-16, MSF-1-7, } \\
\text { IHT-298, AH-14 and EC-601875. }\end{array}$ \\
\hline $\begin{array}{l}\text { 100-seed weight } \\
(>6 \mathrm{~g})\end{array}$ & RHA-297-P, RHA-298-P 3 , AH-14, GPB-51, 1-OH-04-29 and NDLR-06. \\
\hline $\begin{array}{l}\text { Oil per cent } \\
(>40 \%)\end{array}$ & $\begin{array}{l}\text { MSF-1-4, MR-6, EC-601800, EC-512681, RHA-271, 1-OH-07-41, EC- } \\
\text { 152673, EC-152687, MSF-2-16 and EC-512684. }\end{array}$ \\
\hline
\end{tabular}

The selection based on seed yield, plant height, duration of reproductive phase, hull content and oil yield would be more productive. As the selection is valuable for those characters having high heritability with high genetic advance, the lower variability coefficients for days to maturity indicated that there was less genetic variation for this trait in the material evaluated. No accession was found to be promising for all the quantitative characters. However, some accessions could be identified as promising for different traits (Table 5). Thus, a gene pool can be generated by constituting the germplasm lines of interest or by creating a broad based cross. Such material could be useful as a base population to develop promising populations and lines.

\section{References}

Ashok S, Lakshminarayana S and Kumaresan D 2000. Variability studies in sunflower for yield and yield attributes in sunflower. J. Oilseed Res. 17(2): 239-241.

Burton GW 1952. Quantitative inheritance in grasses. Proc. $6^{\text {th }}$ Grassland Congr. 1: $356-363$.

Burton GW and Devane EH 1953. Estimating heritability in tall fesque (Festuca arundinaceae) from replicated clonal material. Agron. J. 45: 478-81.

Dehkhoda A, Naderidarbaghshahi M, Rezaei A and Majdnasiri B 2013. Effect of water deficiency stress on yield and yield component of sunflower cultivars in Isfahan. Intl. J. Farming All Sci. 2(S2): 1319-1324.

Dhillon SP, Chandra PK, Bajaj and Singh P 2010. Genetic Evaluation and characterization of sunflower (Helianthus anпииs L.) Genotypes as per DUS Guidelines. Indian J. Plant Genet. Res. 24: 23-26. 
Diederichsen A 2010. Phenotypic diversity of Jerusalem artichoke (Helianthus tuberosus L.) germplasm preserved by the Canadian genebank. Helia 33(53): 1-16.

Encheva J, Christov M and Shindrova P 2008. Developing mutant sunflower (Helianthus annuus L.) by combined use of classical method with induced mutagenesis and embryo culture method. Bul. J. Agric. Sci. 14: 397-404.

Fick GN, Zimmer DE and Zimmerman DC 1974. Correlation of seed oil content in sunflower with other plant and seed characteristics. Crop Sci. 14: 755-757.

Gangappa E 1991. Evaluation of sunflower germplasm. Crop Sci. 15: 77-78.

Hanson GH, Robinson HF and Comstock RE 1956. Biometrical studies of yield segregating population of Korean lespedeza. Agron. J. 48: 267-82.

Ion V, Dicu G, Basa AG, Dumbrava M, Temocico G, Epure LI and State D 2015. Sunflower yield and yield component under different sowing condition. Agric. Agricult. Sci. Procedia. 6: 44-51.

Jonson HW, HF Robinson and RE Comstock 1955. Estimates of genetic and environmental variability in soybean. Agron. J. 47: 314-18.

Kalukhe VK, Moon MK, Magar NM and Patil SS 2010. Genetic variability in sunflower (Helianthus annuus L.). Bioinfolet. 7: 197-00.

Krishnawat BRS and Sharma SP 1998. Genetic variability in wheat under moisture stress conditions. Crop Res. 16(3): 314-317.

Kshirsagar AR, Deshmukh DT and Dudhe RS 1955. Study of genetic variability in sunflower. PKV Res. J. 19: 175 .

Lakshmanaiah VH 1980. Genetic variability and association of morphological characters with seed yield and oil content in sunflower (Helianthus annuus L.). Mysore J. Agric. Sci.14: 259-261.

Makane VG, Shinde CA, Mohrir MN, Shaikh MD, Shoyab SM and Majid AMA 2011. Genetic variability studies in new versions of sunflower (Helianthus annuus L.). Bioinfolet. 8: 44-51.

Makane VG, Shinde CA, Mohrir MN, Shoyab SM and Majid AMA 2011. Genetic variability studies in new versions of sunflower (Helianthus annuus L.). Bioinfolet. 8: 44-51.

Manjula K 1997. Genetic variability and path coefficient analysis in non-oilseed sunflower (Helianthus annuus L.) genotypes. M.Sc. (Agri.) Thesis, Univ. Agric. Sci., Bangalore, pp. 143.

Mogali SC 1993. Characterization and evaluation of sunflower (Helianthus annuus L.) germplasm. M.Sc. (Agri.) Thesis, Univ. Agric. Sci., Bangalore, pp. 97.

Onemli F and Gucer T 2010. The characterization of some wild species of Helianthus for some morphological traits. Helia 33(53): 17-24.

Panse VG 1957. Genetics of quantitative characters in relation to plant breeding. Ind. J. Genet. 17: 381-387.

Patil BR, M Rudraradhya, CHM Vijayakumar, H Basappa, and K Virupakshappa 1996. Genetic variability in sunflower (Helianthus annuus L.). J. Oilseeds Res.13: 157-161.

Rafiei F, Darbaghshahi MRN, Rezai A and Nasiri BM 2013. Survey of yield and yield components of sunflower cultivars under drought stress. Intel. J. Adv. Biol. Biomed. Res. 1(12): 1628-1638.

Reddy AV and Reddy RN 2006. Evaluation and characterization of Sunflower, (Helianthus annuus L.) germplasm accessions. J. Oilseeds Res. 23: 161-64.

Satisha 1995. Evaluation of sunflower (Helianthus annuus L.) germplasm for yield and yield components. M.Sc. (Agri.) Thesis, Univ. Agric. Sci., Bangalore, pp. 93.

Singh B, Sachan JN and Singh D 1977. Variability and correlation in sunflower (Helianthus annuus L.). Panthnagar, J. Res. 2: 22-30.

Srivastava AN and Mushra R 1976. Genotypic and phenotypic variability in quantitative characters in sunflower. Madras Agric. J. 63: 209-210.

Sultana $\mathrm{T}$ and Ghafoor A 2008. Genetic diversity in ex-situ conserved Lens culinaris for botanical descriptors, biochemical and molecular markers and identification of landraces from Indigenous genetic resources of Pakistan. J. Integr. Plant Biol. 50: 484-490. 
Suma Mogali C and Virupakshappa K 1994. Characterisation and evaluation of sunflower (Helianthus annuus L.) germplasm. Indian J. Pl. Breeding 54: 360-65.

Tan AS and Tan A 2011. Genetic resources of sunflower (Helianthus annuus L.) in Turkey. Helia 34(55): $39-46$.

Velkov VN 1980. Relation between yield and some characters in sunflower. Genetica Selektsiya 13b(5): 329-338.

Virupakshappa K and Sindagi SS 1988. A note on germplasm collections in sunflower. J. Oilseeds Res. 5: $119-120$

(Manuscript received on 23 May, 2018; revised on 18 October, 2018) 